\title{
THE FIRST NEW JERSEY IMPRINT
}

\author{
BY GEORGE C. ROCKEFELLER
}

\begin{abstract}
Mr. Rockefeller is a bibliographer and collector with a special interest in early New Jersey imprints.
\end{abstract}

\begin{abstract}
7 UTGERS University Library has recently become the owner of the first New Jersey imprint. One of the highlights of 1 printing in colonial America, it was part of the collection of Thomas W. Streeter of Morristown, and before the sale was the only copy still in private hands. The volume contains three Acts passed by the legislature at Burlington on the 3oth day of November, 1723 . The title page reads:
\end{abstract}

Anno Regni Georgii Regis Magnæ Britanniæ, Franciæ \& Hiberniæ Decimo, At a Session of the General Assembly of the Colony of New-Jersey, begun the twenty fourth Day of September, Anno Domini 1723 and continued by Adjournments to the 3oth Day of November following, at which time the following Acts were Published. [Royal Arms.] Printed by William Bradford in the City of Perth-Amboy, 1723.

William Bradford had introduced printing to Pennsylvania in I 685 and to New York in I 693. He printed the first session laws of New Jersey in 1703 in New York and in I 717 became "Printer to the King's Most Excellent Majesty for the Province of New Jersey."'

Although Perth Amboy is stated to be the place of printing of the Acts of 1723 , some authorities on colonial printing have maintained that the volume was produced by William Bradford's press in New York. This question arose because of the fact that copies exist with identical title pages except for imprints reading "Printed by William Bradford in the City of New York, I 723."

Mr. Lawrence C. Wroth, an authority on early American printing, was the first to advance the theory that Bradford moved his press from New York to Perth Amboy in order to print an issue of paper currency; having done so, Wroth suggests, Bradford then printed an edition of the recent Assembly statutes. He points out a parallel case where, in 1728 , when a new issue of currency was

${ }^{1}$ Imprint from laws of 1717 . Copy at Rutgers University Library. 
authorized, Samuel Keimer, who had secured the printing contract, moved his press from Philadelphia to Burlington and there printed a volume of laws. ${ }^{2}$

The late Mr. Douglas McMurtrie, author of many works on the pioneer presses of the United States, explored the question of place of printing very thoroughly in two articles in the Proceedings of the New Jersey Historical Society: "The Earliest New Jersey Imprint," Vol. 50 (1932), I9I-202; and "A Further Note on the New Jersey Acts of I723," Vol. 53 (1935), I-8. The information in these two articles was used as the first part of the chapter on New Jersey in the author's $A$ History of Printing in the United States (New York, I 936). Mr. McMurtrie goes further than Mr. Wroth noting that it is highly probable that copies with the New York imprint were also printed in Perth Amboy.

There are further complications. Both $\mathrm{Mr}$. Wroth and $\mathrm{Mr}$. McMurtrie place the printing of the currency previous to the printing of the Acts. This is the reverse of the actual sequence if the date of I 723 on the title page of the Acts is correct. Presuming that it is, the statutes were printed first, probably in December 1723 . The paper currency, of which several examples are known, is dated March 25, 1724 , and was, without doubt, printed on or after that date.

Still another problem is the appointment of Samuel Keimer as printer of the currency authorized by the Act of $1723 .^{3}$ Specimens of the currency examined ${ }^{4}$ do not show the printer's name, but it was Mr. Wroth's belief that it was printed by William Bradford in New Jersey because Keimer was evidently then incapable of printing the issue. ${ }^{5}$

Although Mr. McMurtrie does not offer conclusive proof that the volume was printed in Perth Amboy, he has identified three different editions. As previously noted, one edition carries on the title page "Printed in the City of Perth Amboy, I 723" and the other "Printed in the City of New York, I723." A copy with the New

${ }^{2}$ Chapter entitled "North America (English-Speaking)" in Printing-A Short History of the Art, ed. R. A. Peddie (London, 1927). This chapter was expanded into The Colonial Printer (New York, 193r) and (Portland, Maine, 1938).

${ }^{3}$ This was pointed out to the author by Mr. Alexander J. Wall, Jr., then Director of the New Jersey Historical Society.

${ }^{4}$ In the Emmit Collection, at NYPL. $\quad{ }^{3}$ Letter from Mr. Wall, May 3, 1956. 
York imprint, in the New Jersey State Library, has the final pages reset, making a third edition.

The Rutgers copy is one of two copies with 33 pages containing three Acts. All other copies have only 32 pages, lacking the third Act, except the one with the text reset which contains the three Acts within 30 pages. In two copies with the Perth Amboy imprint there are four unnumbered pages at the end, with the heading "Tables shewing the Principal and Interest that the Borrowers of New-Jersey Paper Money must pay in, yearly, to the Respective Loan-Offices, during the Term of Twelve years." These four pages, which Mr. McMurtrie says are not an integral part of the Acts as printed in I 723, do not appear in the Rutgers copy.

The first Act, pages 3-26, entitled "An Act for an Additional Support of this Government," provides for $\mathfrak{E}_{40}$,000 of paper currency to be issued to private borrowers, the loans to be secured by mortgages on real estate. There is a provision for an oath to be taken by the printer of the Bills of Credit to safeguard their proper printing and for the delivery of the notes by the printer to named officials. ${ }^{\circ}$

The second Act, pages 26-32, is entitled "An Act concerning the duty of the Commissioners appointed to manage the Loan Offices in the respective counties of this Province." At the foot of page 32 is the line "Published the 3oth Day of November, I 723."

The third Act, which is complete on page 33, is entitled "An Act for the better and more effectual putting in Execution an Act ... for Regulating Fences"; at the foot of the page appears the line "Published at Burlington the 30 th of November, I723." As Mr. McMurtrie states, this implies promulgation, rather than printing, at Burlington.

These Acts are included in the compilation of New Jersey laws edited by Samuel Nevill and printed by William Bradford (the second) in Philadelphia in I 752, being Chapters XXXVI, XXXVII and XXXVIII, pages I03 to I 38 .

\footnotetext{
${ }^{6}$ For other provisions see Edwin P. Tanner, The Province of New Jersey, $1664^{-1738}$ (New York, 1908), pp. 509-511.
} 